\title{
Mecanismos e Efeitos da Internalização de Nanotubos de Carbono de Parede Simples Sobre o Ciclo Celular
}

\begin{abstract}
Dissertação apresentada ao Programa de PósGraduação em Biologia Celular e Tecidual do Instituto de Ciências Biomédicas da Universidade de São Paulo, para a obtenção do título de Mestre em Ciências.

Área de concentração: Biologia Celular e Tecidual

Orientadora: Profa. Dra. Gláucia Maria Machado
\end{abstract} Santelli

Versão original 


\section{RESUMO}

Souza MM Mecanismos e efeitos da internalização de nanotubos de carbono de parede simples sobre o ciclo celular. [Dissertação (Mestrado em Ciências)]. São Paulo: Instituto de Ciências Biomédicas, Universidade de São Paulo]; 2014.

O presente trabalho teve por objetivo avaliar alterações devido à exposição a Nanotubos de Carbono de Parede Simples (NTCPS) em duas linhagens celulares epiteliais (BBnt e HK2) e em uma linhagem celular monocítica (THP-1), enfocando os mecanismos de internalização e os efeitos sobre o ciclo celular. Foi avaliada a ação dos receptores scavenger na internalização dos NTCPS nas células HK2 e THP-1 e a interferência de duas concentrações de NTCPS sobre os elementos do citoesqueleto e no ciclo celular, nas células HK2 e BBnt. As concentrações utilizadas foram equivalentes as permitidas pelo The National Institute for Occupational Safety and Health: 2,4 e $24 \mathrm{\mu g} / \mathrm{cm}^{2}$. A análise de expressão de mRNA por RT-PCR para receptores scavenger, mostrou que a internalização do NTCPS pode ocorre por endocitose. Sendo que os receptores SCARA5 e SRA são os responsáveis pela internalização nas células THP-1, enquanto MARCO e SRA realizam o processo de internalização nas células HK2. Observou-se que em ambas as concentrações, as células BBnt apresentaram amplificação centrossômica, com a ocorrência de 25,38\% e $28,46 \%$ de mitoses alteradas para cada concentração, respectivamente. Não houve interferência significativa na progressão do ciclo celular em ambas as linhagens. O estudo da interação dos NTCPS com vesículas lipídicas não apresentou evidencias de alterações ou danos na membrana das vesículas, porém as vesículas apresentaram-se associadas umas às outras após o tratamento com $24 \mu \mathrm{g} / \mathrm{cm}^{2}$.

Palavras-chave: Nanotubos de carbono. Internalização. Receptores scavenger. Amplificação centrossômica 


\begin{abstract}
Souza MM Mechanisms and effects of internalization of single wall carbon nanotube in cell cycle. [Master thesis (Science)]. São Paulo: Instituto de Ciências Biomédicas, Universidade de São Paulo; 2014.

This study aimed to assess changes due to exposure to of Single-wall Carbon Nanotubes (SWCNT) in two epithelial cell lines (BBnt and HK2) and a monocytic cell line (THP-1), focusing on the mechanisms of internalization and effects on the cell cycle. The action of scavenger receptors in the internalization of SWNTC in HK2 and THP-1 cells and the interference of two concentrations of SWNTC about elements of the cytoskeleton and the cell cycle, in BBnt and HK2 cells was evaluated. The concentrations used were equivalent to those allowed by The National Institute for Occupational Safety and Health: 2,4 to $24 \mu \mathrm{g} / \mathrm{cm}^{2}$. Analysis of mRNA expression by RT-PCR for scavenger receptors showed that the SWNTC internalization can occurs by endocytosis. Being that SCARA5 and SRA receptors are responsible for internalization in THP-1 cells, while MARCO and SRA perform the process of internalization in HK2 cells. It was observed that at both concentrations, the cells showed centrosome amplification in BBnt cells, with the occurrence of $25.38 \%$ and $28.46 \%$ of mitosis changed for each concentration, respectively. There was no significant interference with cell cycle progression in both strains. The study of the interaction of lipid vesicles with SWNTC showed no evidence of change or damage the membrane of the vesicles, but the vesicles were associated with each other after treatment with $24 \mu \mathrm{g} / \mathrm{cm}^{2}$.
\end{abstract}

Keywords: Carbon nanotubes. Internalization. Scavenger receptors. Centrosome amplification 


\section{INTRODUÇÃO}

Nanociência diz respeito a todas as estruturas de tamanho nanométrico (um bilionésimo de metro). Uma das primeiras implicações nesta área é o papel dominante da superfície. O aumento da área da superfície é muito útil em muitos campos como, por exemplo, na entrega da droga ou na catálise. Esta é apenas uma das muitas características da nanoescala, de fato nanoestruturas possuem muitas outras propriedades peculiares, dando origem a uma ampla gama de aplicações em física, química, engenharia, biologia e medicina. Várias novas subáreas foram recentemente iniciadas, tal como, por exemplo, "nanomedicina" e "nanoengenharia". A descoberta e as aplicações subsequentes de nanotubos de carbono (NTC) têm permitido o desenvolvimento de todo um ramo da nanotecnologia com base neste material versátil. NTCs têm sido considerados um material versátil com potencial para aplicações em diversos produtos, como: dispositivos eletrônicos, biomédicos, catalisadores e adsorventes. Grande parte destas aplicações são possíveis devido ao tamanho nanométrico e a elevada área superficial dos NTCs alterarem de maneira significativa as suas propriedades químicas e físicas. Apesar das grandes possibilidades, do interesse e investimentos em NTCs, os efeitos toxicológicos desse material ainda não estão completamente avaliados. Tem sido relatado que as características dos NTCs os tornam em potenciais agentes toxicológicos. Entretanto, na tentativa de contornar o problema da citotoxidade e genotoxicidade e tornar os NTCs úteis para este tipo de aplicações, tem sido utilizada a estratégia para modificar os NTCs por meio de reações que adicionam grupos funcionais sobre a superfície dos NTCs, tais como polímeros, proteínas ou ácidos nucléicos para torná-los biocompatíveis. Porém para que as aplicações se tornem realidade ainda é necessário esclarecer quais mecanismos as células internalizam os NTCs.

A compreensão dos mecanismos de internalização pode ser útil em aplicações de $d r u g$ delivery (para entrega drogas ou biomoléculas), terapia para câncer, agente de contraste para diagnóstico por imagem, entre outras. Estudos têm apontado que as células podem internalizar os NTCs por dois mecanismos diferentes, são eles: processos dependente de energia (fagocitose e endocitose) e a internalização por processo independente de energia (difusão passiva) [1]. A internalização por fagocitose tem sido observada quando os NTCS na forma de agregados com tamanho que varia de algumas centenas de nanômetros até alguns micrômetros [2]. Quando os NTCs apresentam dimensões elevadas o processo de fagocitose pode não ser bem sucedido. Esse processo é conhecido como fagocitose "frustrada" e tem sido associado à respostas inflamatórias [3-5]. Nas células não especializadas em fagocitose, o processo de internalização dos NTCs ocorre por via endocítica, mediada por receptores de membrana. O conhecimento sobre o papel de receptores de superfície de membrana na internalização, motivou a utilização NTCs conjugados como agentes quimioterápicos e com ligantes específicos a receptores superexpressados em células cancerosas. Um exemplo é o uso de receptores de EGF ou de ácido fólico para realizar uma internalização seletiva e aumentar a eficiência dos quimioterápicos $[6,7]$.

Uma família de receptores de superfície da membrana plasmática bem conhecida, são os receptores scavenger [8]. Esses receptores podem ser expressos por células mieloides, endoteliais e algumas células epiteliais e são capazes de reconhecer diferentes ligantes, como patógenos bacterianos e lipoproteínas. Eles têm sido relacionados também com a internalização 


\section{CONSIDERAÇÕES FINAIS}

Ao tratar as linhagens celulares estudadas com NTCPS, observou-se que em baixas concentrações $\left(2,4 \mu \mathrm{g} / \mathrm{cm}^{2}\right.$ e $\left.24 \mu \mathrm{g} / \mathrm{cm}^{2}\right)$ os nanotubos interagem e são internalizados. A expressão relativa de mRNA evidenciou que receptores de membrana plasmática membros da família scavenger estão relacionados com a internalização endocítica dos NTCPS. Os dados obtidos demonstram que diferentes receptores desta família podem atuar durante o processo de internalização e um aumento da expressão de mRNA é estimulado pelo aumento na concentração de NTCPS. Por meio da microscopia Raman ficou evidente a interação dos nanotubos de carbono com células epiteliais derivadas de carcinoma de pulmão humano. Embora os nanotubos de carbono tenham sido internalizados, os efeitos observados sobre a interferência no ciclo celular não foram estatisticamente significativos. Esses resultados indicam que os efeitos dos NTCPS nas células BBNT e HK2 se apresentaram menos tóxicos do que aqueles observados para células primarias e normais do epitélio pulmonar humano [19] ou para células de provenientes de rato ou camundongo [56,57]. Enquanto que, para a linhagem celular BBNT houve alterações no padrão das mitoses, levando a células dessa linhagem a gerarem mitoses multipolares. O que pode ser um efeito resultante da interação dos NTCPS com os centrossomos durante o processo de divisão. A análise da interação dos nanotubos de carbono com vesículas unilamelar gigante não apresentou alterações que indicassem uma interação entre os nanotubos e as vesículas. Entretanto, foi visualizado uma interação vesícula-vesícula não usual que, pode indicar uma influência dos nanotubos de carbono sobre o comportamento das vesículas. Contudo esses estudos devem ser aprofundados para determinar se esse comportamento é resultante da ação dos NTCPS. Conjuntamente os efeitos da exposição a longo prazo e a efetividade da internalização devem ser exploradas de maneira a elucidar como os nanotubos de carbono podem influenciar a integridade celular. 


\section{REFERÊNCIAS*}

[1] Kostarelos k, Larceda L, Bianco A. Cellular uptake of functionalized carbon nanotubes is independent of functional group and cell type. Nat Nano. 2007;2(2):108-13.

[2] Cherukuri P, Bachilo SM, Litovsky SH, Silvio H, Weisman SH. Near-Infrared fluorescence microscopy of single-walled carbon nanotubes in phagocytic cells. Journal of the American Chemical Society. 2004;126(48):15638-39.

[3] Donaldson K, Murphy F, Duffin R, Poland C. Asbestos, carbon nanotubes and the pleural mesothelium: a review of the hypothesis regarding the role of long fibre retention in the parietal pleura, inflammation and mesothelioma. Particle and Fibre Toxicology. 2010;7(1):5.

[4] Murphy F, Schinwald A, Poland CA, Donaldson K. The mechanism of pleural inflammation by long carbon nanotubes: interaction of long fibres with macrophages stimulates them to amplify pro-inflammatory responses in mesothelial cellss. Particle and Fibre Toxicology. 2010;9(8):2-15.

[5] Brown DM, Kinloch IA, Bangert U, Windle AH, et al. An in vitro study of the potential of carbon nanotubes and nanofibres to induce inflammatory mediators and frustrated phagocytosis. Carbon. 2007;45(9):1743-56.

[6] Heister E, Neves V, C T, McFadden J, et al. Triple functionalisation of single-walled carbon nanotubes with doxorubicin, a monoclonal antibody, and a fluorescent marker for targeted cancer therapy. Carbon. 2009;47(9):2152-60.

[7] Bhirde AA, Patel V, Gavard J, Rusling JF, et al. Targeted killing of cancer cells in vivo and in vitro with EGF-Directed carbon nanotube-based drug delivery. ACS Nano. $2009 ; 3(2): 307-16$.

[8] Pluddemann A, Neyen C, Gordon S. Macrophage scavenger receptors and host-derived ligands. Methods. 2007;43(3):207-17.

[9] Hirano S, Fujitani Y, Furuyama A, Kanno S. Macrophage receptor with collagenous structure (MARCO) is a dynamic adhesive molecule that enhances uptake of carbon nanotubes by CHO-K 1 cells. Toxicology and Applied Pharmacology. 2012;259(1):96-103.

[10] Gao N, Zhang G, Mu Q, Yan B, et al. Steering carbon nanotubes to scavenger receptor recognition by nanotube surface chemistry modification partially alleviates $\mathrm{NF} \kappa \mathrm{B}$ activation and reduces its immunotoxicity. ACS Nano. 2011;5(6):4581-91.

[11] Iijima S. Helical microtubules of graphitic carbon. Nature. 1991;354(6348):56-8.

[12] Gregan E, Keogh SM, Hedderman TM, Chamgers G, Byrne HJ. Stokes/anti-Stokes Raman spectroscopy of highpressure carbon oxide (HiPco) single-walled carbon nanotubes. Proc SPIE. 2003;4876:1149-57.

*De acordo com: International Committee of Medical Journal Editors. [Internet]. Uniform requirements for manuscripts submited to biomedical journals. [2011 Jul 15]. Available from:http://www.nlm.nih.gov/bsd/uniform _ requirements.html. 
[13] Zheng LX, Connell MJ, Doorn SK, Liao XZ, Zhao YH, Akhadov EA, et al. Ultralong single-wall carbon nanotubes. Nat Mater. 2004;3(10):673-76.

[14] Hirschmann T. physicsworld, editor. Scientists delve deeper into carbon nanotubes. http://physicsworld.com/cws/article/news/2013/feb/19/scientists-delve-deeper-intocarbon-nanotubes; 2014. Accessed August, 4.

[15] Choudhary V, Gupta A. Yellampalli S, editor. Carbon nanotubes - polymer nanocomposites. http://www.intechopen.com/books/export/citation/BibTex/carbon-nanotubespolymer-nanocomposites/polymer-carbon-nanotube-nanocomposites; 2011. Accessed August, 4 .

[16] Ando Y, Zhao X, Sugai T, Kumar M. Growing carbon nanotubes. Materials Today. 2007;7(10):22-9.

[17] Lam CW, James JT, McCluskey R, Arepalli S, Hunter RL. A review of carbon nanotube toxicity and assessment of potential occupational and environmental health risks. Crit Rev Toxicol. 2006;36(3):189-217.

[18] Nikolaev P, Bronikowski MJ, Bradley RK, Rohmund F, Colbert DT, Smalley RE. Gasphase catalytic growth of single-walled carbon nanotubes from carbon monoxide. Chem Phys Letter. 2006;313(1):91-7.

[19] Wagner HD. Reinforcement. In: Encyclopedia of Polymer Science and Technology. New York: John Wiley Sons, Inc.; 2002. p. 94-15.

[20] Endo M, S MS, Ajayan P, M P. Potential applications of carbon nanotubes. In: Jorio A, Dresselhaus G, Dresselhaus MS, editors. Carbon nanotubes. vol. 111 of Topics in Applied Physics. Springer Berlin Heidelberg; 2008. p. 13-62.

[21] Bhushan B. Springer Handbook of Nanotechnolog. In: B B, editor. Springer handbook of nanotechnology. Springer Berlin Heidelberg; 2007. p. 1-12.

[22] Tsang SC, Oliveira JJ, Davis MLH Green, Hill HOA. The structure of the carbon nanotube and its surface topography probed by transmission electron microscopy and atomic force microscopy. Chemical Physics Letters. 1996;249(5â6):413 -22.

[23] Monthioux M, Smith BW, Burteaux B, Claye A, Fischer JE, Luzzi DE. Sensitivity of single-wall carbon nanotubes to chemical processing: an electron microscopy investigation. Carbon. 2001;39(8):1251-72.

[24] Saito R, Fujita M, Dresselhaus G, Dresselhaus MS. Electronic structure of chiral graphene tubules. Applied Physics Letters. 1992;60(18):2204-06.

[25] Hamada N, Sawada Si, Oshiyama A. New one-dimensional conductors: Graphitic microtubules. Phys Rev Lett. 1992;68:1579-81.

[26] Poole CP, Owens FJ. Introduction to Nanotechnology. New York: Wiley Sons; 2003. 
[27] Berber S, Kwon YK, Tománek D. Unusually high thermal conductivity of carbon nanotubes. Phys Rev Lett. 2000;84:4613-16.

[28] Baughman RH, Zakhidov AA, Heer WA. Carbon nanotubes: the route toward applications. Science. 2002;297:787-92.

[29] Yu M, Lourie O, Dyer MJ, Moloni K, Kelly TF, Ruoff RS. Strength and breaking mechanism of multiwalled carbon nanotubes under tensile load. Science. 2000;287:637-40.

[30] Walters DA, Ericson LM, Casavant MJ, Liu J, Colbert DT, Smith KA, et al. Elastic strain of freely suspended single-wall carbon nanotube ropes. Applied Physics Letters. 1999;74(25):3803-05.

[31] Yakobson BI, Brabec CJ, Bernholc J. Nanomechanics of carbon tubes: instabilities beyond linear response. Phys Rev Lett. 1996;76:2511-2514.

[32] Wong EW, Sheehan PE, Lieber CM. Nanobeam mechanics: elasticity, strength, and toughness of nanorods and nanotubes. Science. 1997;277(5334):1971-75.

[33] Zhao J, Buldum A, Han J, Ping Lu J. First-principles study of Li-intercalated carbon nanotube ropes. Phys Rev Lett. 2000;85:1706-09.

[34] Cadek M, Coleman JN, Barron V, Hedicke K, Blau WJ. Morphological and mechanical properties of carbon-nanotube-reinforced semicrystalline and amorphous polymer composites. Applied Physics Letters. 2002;81(27):5123-25.

[35] Tasca F, Gorton L, Wagner JB, Noll G. Increasing amperometric biosensor sensitivity by length fractionated single-walled carbon nanotubes. Biosensors and Bioelectronics. $2008 ; 24(2): 272-78$.

[36] Cheung CL, Hafner JH, Odom TW, Kim K, Lieber CM. Growth and fabrication with single-walled carbon nanotube probe microscopy tips. Applied Physics Letters. 2000;76(21):3136-38.

[37] Bianco A, Kostarelos K, Prato M. Applications of carbon nanotubes in drug delivery. Current Opinion in Chemical Biology. 2005;9(6):674-79.

[38] Zhao Q, Gan Z, Zhuang Q. Electrochemical sensing based on carbon nanotubes. TrAC Trends in Analytical Chemistry. 2010;29(9):939-53.

[39] Wei T, Fan Z, Luo G, Wei F, Zhao D, Fan J. The effect of carbon nanotubes microstructures on reinforcing properties of SWNTs/alumina composite. Materials Research Bulletin. 2008;43(10):2806-809.

[40] Cooke WE. Pulmonary Asbestosis. Br Med J. 1927;2(3491):1024-25.

[41] Smart S, Cassady A, Lu G, Martin D. The biocompatibility of carbon nanotubes. Carbon. $2006 ; 44(6): 1034-47$. 
[42] Dumortier H, Lacotte S, Pastorin G, Marega R, Wu W, Bonifazi D, et al. Functionalized carbon nanotubes are non-cytotoxic and preserve the functionality of primary immune cell. Nano Letters. 2006;6(7):1522-28.

[43] Wick P, Manser P, Limbach L, Dettlaff-Weglikowska U, Krumeich F, Roth S, et al. The degree and kind of agglomeration affect carbon nanotube cytotoxicity. Toxicology Letters. 2007;168(2):121-131.

[44] Sayes C, Liang F, Hudson J, Mendez J, Guo W, Beach J, et al. Functionalization density dependence of single-walled carbon nanotubes cytotoxicity in vitro. Toxicol Letters. 2006;161(2):135-42.

[45] Poland C, Duffin R, Kinloch I, Maynard A, Wallace W, Seaton A, et al. Carbon nanotubes introduced into the abdominal cavity of mice show asbestos-like pathogenicity in a pilot study. Nat Nano. 2006;3(7):423-28.

[46] Goodglick L, Kane A. Cytotoxicity of long and short crocidolite asbestos fibers in vitro and in vivo. Cancer Research. 2006;50(3):5153-63.

[47] Oberdorster G, Maynard A, K D, Castranova V, et al. Principles for characterizing the potential human health effects from exposure to nanomaterials: elements of a screening strategy. Part Fibre Toxicol. 2005;6(2):8.

[48] Pryor WA. Oxy-radicals and related species: their formation, lifetimes, and reactions. Annu Rev Physiol. 1986;48:657-67.

[49] J M, F H, D L. Respiratory Toxicity of multiwalled carbon nanotubes: How worried should we be? Carbon. 2006;44(6):1048-56.

[50] Borm PJ, Robbins D, Haubold S, Fissan H, Donaldson K, Schins R, et al. The potential risks of nanomaterials: a review carried out for ECETOC. Part Fibire Toxixol. $2006 ; 14(3): 11$.

[51] Nel AE, Madler L, Velegol D, Xia T, Hoek EMV, Somasundaran P, et al. Understanding biophysicochemical interactions at the nano-bio interface. Nat Mat. 2009;8(7):543-57.

[52] Zhang QW, Kusaka Y, Sato K, Nakakuki K, Kohyama N, Donaldson K. Differences in the extent of inflammation caused by intratracheal exposure to three ultrafine metals: role of free radicals. J Toxicol Environ Health. 1998;53(6):423-38.

[53] J BP. Particle toxicology: from coal mining to nanotechnology. Inhal Toxicol. 2002;14(3):311-24.

[54] Buzea C, Pacheco I, K R. Nanomaterials and nanoparticles: sourcesand toxicity. Biointerphases. 2007;2(4):M17-M71.

[55] Schlesinger RB. Toxicological evidence for health effects from inhaled particulate pollution: does it support the human experience? Inhal Toxicol. 1995;7(1):99-109. 
[56] Oberdorster G, Ferin J, Lehnert BE. Correlation between particle-size, in-vivo particle persistence, and lung injury. Environ Health Perspect. 1994;102(5):173-79.

[57] Holsapple MP, Farland WH, Landry TD, Monteiro-Riviere NA, Carter JM, Walker NJ, et al. Research strategies for safety evaluation of nanomaterials, part II: Toxicological and safety evaluation of nanomaterials, current challenges and data needs. Toxicol Sci. $2005 ; 88(1): 12-7$.

[58] Linkov I, Satterstrom FK, Corey LM. Nanotoxicology and nanomedicine:making hard decisions. Nanomedice. 2008;4(2):167-71.

[59] Suh WH, Suslick SK, Stucky GD, Suh YH. Nanotechnology,nanotoxicology, and neuroscience. Prog Neurobiol. 2009;87(3):133-70.

[60] Wick P, Manser P, Limbach L, Dettlaff-Weglikowska U, Krumeich F, Roth S, et al. The degree and kind of agglomeration affect carbon nanotube cytotoxicity. Toxicology Letters. 2007;168(2):121-31.

[61] Smart S, Cassady A, Lu G, Martin D. The biocompatibility of carbon nanotubes. Carbon. 2006;44(6):1034-47.

[62] Dumortier H, Lacotte S, Pastorin G, Marega R, Wu W, Bonifazi D, et al. Functionalized carbon nanotubes are non-cytotoxic and preserve the functionality of primary immune cells. Nanno Lett. 2006;6(7):1522-28.

[63] Doak SH, Griffiths SM, B M, et al. Confounding experimental considerations in nanogenotoxicology. Mutagenesis. 2009;24(4):285-93.

[64] Sargent LM, Shvedova AA, Hubbs AF, et al. Induction of aneuploidy by single-walled carbon nanotubes. Environmental and Molecular Mutagenesis. 2009;50(8):708-17.

[65] Muller J, Decordie I, Hoet PH, Kirsch-Volders M, et al. Clastogenic and aneugenic effects of multi-wall carbon nanotubes in epithelial cells. Carcinogenesis. 2008;29(2):427-33.

[66] Shvedova AA, Kisin ER, Mercer R, BaronR, et al. Unusual inflammatory and fibrogenic pulmonary responses to single-walled carbon nanotubes in mice. American Journal of Physiology - Lung Cellular and Molecular Physiology. 2005;289(5):L698-L708.

[67] Asakura M, Sasaki T, Sugiyama T, Takaya M, Koda S, et al. Genotoxicity and cytotoxicity of multi-wall carbon nanotubes in cultured chinese hamster lung cells in comparison with chrysotile fibers. Journal of Occupational Health. 2010;52(3):155-66.

[68] Cortez BA, Machado-Santelli GM. Chrysotile effects on human lung cell carcinoma in culture: 3-D reconstruction and DNA quantification by image analysis. BMC Cancer. 2008;8(181):1-10.

[69] Cortez BA, Quassollo G, Caceres A, Machado-Santelli GM. The fate of chrysotile-induced multipolar mitosis and aneuploid population in cultured lung cancer cells. Biological Sciencesi. 2011;6(4):e18600. 
[70] Sargent LM, Hubbs AF, Young SH, Kashon ML, Dinub CZ, Salisbury JL, et al. Singlewalled carbon nanotube-induced mitotic disruption. Mutat Res. 2012;45:28-37.

[71] Shim M, Shi K, Chen R, Dai H, et al. Functionalization of carbon nanotubes for biocompatibility and biomolecular recognition. Nano Letters. 2002;2(4):285-88.

[72] Madan S, Mandel A, Seifalian A. A concise review of carbon nanotube's toxicology. Nano Reviews. 2013;4(0):1-26.

[73] Balasubramanian K, Burghard M. Chemically functionalized carbon nanotubes. Small. 2005;1(2):180-92.

[74] Castillo JJ, Rindzevicius T, Novoa LV, Svendsen WE, Rozlosnik N, Boisen A, et al. Noncovalent conjugates of single-walled carbon nanotubes and folic acid for interaction with cells over-expressing folate receptors. J Mater Chem B. 2013;1:1475-81.

[75] Murphy JE, Tedbury PR, Homer-Vanniasinkam S, Walker JH, Ponnambalam S. Biochemistry and cell biology of mammalian scavenger receptors. Atherosclerosis. 2005;182(1):115.

[76] Wang X, Guo J, T C, Nie H, Wang H, Zang J, et al. Multi-walled carbon nanotubes induce apoptosis via mitochondrial pathway and scavenger receptor. Toxicology in Vitro. 2012;26(6):799-06.

[77] MartÃnez VG, Moestrup SK, Holmskov U, Mollenhauer J, Lozano F. Conserved scavenger receptor cysteine-rich superfamily in therapy and diagnosis. Pharmacol Rev. 2011;63(4):967-1000.

[78] Santiago-Garcia J, Kodama T, Pitas RE. The class A scavenger receptor binds to proteoglycans and mediates adhesion of macrophages to the extracellular matrix. J Biol Chem. 2003;278:6942-46.

[79] Chao SK, Hamilton RF, Pfau JC, Holian A. Cell surface regulation of silica-induced apoptosis by the SR-A scavenger receptor in a murine lung macrophage cell line (MH-S). Toxicol Appl Pharmacol. 2003;174(1):10-16.

[80] Areschoug T, Gordon S. Microreview scavenger receptors: role in innate immunity and microbial pathogenesis. Cellular Microbiology. 2009;11(8):1160-69.

[81] Stephen SL, Freestone K, Duun S, Twigg MW, et al. Scavenger receptors and their potential as therapeutic targets in the treatment of cardiovascular. International Journal of Hypertension. 2010;2010:1-20.

[82] Bowdish DM, Gordon S. Conserved domains of the class A scavenger receptors evolution and function. Immunol Rev. 2009;227(1):19-31.

[83] Raymond F, Hamilton JR, Takur SA, Holian A. Silica binding and toxicity in alveolar macrophages. Free Radical Biology e Medicine. Free Radic Biol Med. 2008;44(7):1246-58. 
[84] Greaves DR, Gordon S. The macrophage scavenger receptor at 30 years of age: current knowledge and future challenges. J Lipid Res. 2008;50(SuppL):S282-86.

[85] Peiser L, Gordon S. The function of scavenger receptors expressed by macrophages and their role in the regulation of inflammation. Microbes and Infection. 2001;3(2):149-59.

[86] Silverstein LR, Febbraio M. CD36, a Scavenger receptor involved in immunity, metabolism, angiogenesis, and behavior. Sci Signal. 2001;2(72):re3-re3.

[87] Gao R, Wang ZL, Bai Z, de Heer WA, Dai L, Gao M. Nanomechanics of individual carbon nanotubes from pyrolytically grown arrays. Phys Rev Lett. 2000;85:622-25.

[88] Bonaldo MF, Pestano CB, Ribeiro MC, Machado-Santelli GM, Mori L, Oliveira AR. Comparative characterization of a human large cell lung carcinoma cell line and the xenograft derived cell line. Cell Biol Int Rep. 1991;15(3):229-41.

[89] Bustin SA. Absolute quantification of mRNA using real-time reverse transcription polymerase chain reaction assays. Journal of Molecular Endocrinology. 2000;25(2):169-93.

[90] Bustin SA. Quantification of mRNA using real-time reverse transcription PCR(RT-PCR): trends and problemsy. Journal of Molecular Endocrinology. 2002;29(1):23-9.

[91] Jiang W, Kim BYS, Rutka JT, Chan WCW. Nanoparticle-mediated cellular response is size-dependent. Nat Nanotechnol. 2008;3(3):145-50.

[92] Jin W, Heller DA, Sharma R, Strano MS. Size-Dependent cellular uptake and expulsion of single-walled carbon nanotubes: single article tracking and a generic uptake model for nanoparticles. ACS Nano. 2009;3(1):149-58.

[93] Shi X, Bussche AVD, Hurt RH, Agnes BK, Gao H. Cell entry of one-dimensional nanomaterials occurs by tip recognition and rotation. Nat Nano. 2011;6(11):714-19.

[94] Seferos D, Prigodich B. Polyvalent DNA nanoparticle conjugates stabilize nucleic acids. Nano Lett. 2008;9(1):308-11.

[95] Wang H, Wu L, Reinhardl B. Scavenger receptor mediated endocytosis of silver nanoparticles into J774A1 macrophages is heterogeneous. ACS Nano. 2012;6:7122-32.

[96] Chae S, Um H, lEE JH, Cho H. Centrosome amplification and multinuclear phenotypes are Induced by hydrogen peroxide. Exp Mol Med. 2005;37(5):482-87.

[97] Loffler H, C L, Bartek J. Structure meets function-Centrosomes, genome maintenance and the DNA damage response. Experimental Cell Research. 2006;312(14):2633-40.

[98] Gordon DJ, Resio B, D P. Causes and consequences of aneuploidy in cancer. Nat Rev Genet. 2012;13(3):189-03.

[99] Kim K, Rhee K. The pericentriolar satellite protein CEP90 is crucial for integrity of the mitotic spindle pole,. J Cell Sci,. 2011;124(3):338-47. 
[100] Cimprich K, Lukas C, Lukas J. ATR: an essential regulator of genome integrity. Nature Reviews. 2008;5(10):616-27.

[101] Bartek C, C L, Bartek J. Checking on DNA damage in S phase. Nat Rev Mol Cell Biol. 2004;5(10):792-804.

[102] Zhivotovsky B, Orrenius S. Cell cycle and cell death in disease: past, present and future. Journal of Internal Medicine. 2010;268(5):395-09.

[103] Collins K, Jacks T, Payletich N. The cell cycle and cancer. PNAS. 1997;94(7):2776-78.

[104] Wang J, Sun P, Bao Y, Liu J, An L. Cytotoxicity of single-walled carbon nanotubes on PC12 cells. Toxicology in vitro. 2011;25:242-50.

[105] Cui D, Tian C, Ozkan C, Wang M, Gao H. Effect of single wall carbon nanotubes on human HEK293. Toxicology Letters. 2005;155(1):73-85.

[106] Han Y, Xu J, Li Z, Ren G, Yang Z. In vitro toxicity of multi-walled carbon nanotubes in C6 rat glioma cells. Neuro Toxicology. 2012;33(5):1128-34.

[107] Lipowsky R. In vitro toxicity of multi-walled carbon nanotubes in C6 rat glioma cells. Current Opinion in Structural Biology. 1995;5(5):531-40.

[108] Imparato A, Shillcock JC, Lipowsky R. Shape fluctuations and elastic properties of twocomponent bilayer membranes. Europhys. 2005;69(4):650-56.

[109] Linke GT, Lipowsky R, Gruhn T. Free fluid vesicles are not exactly spherical. Physical Review. 2005;71(5):051602.

[110] Lipowsky R, Brinkmann M, Dimova R, Haluska C, Kierfeld J, Shillcock J. Wetting, budding, and fusion-morphological transitions of soft surfaces. Journal of Physics-Condensed Matter. 2005;17(31):S2885-902.

[111] Blinder WH, Sachsenhofer R, Farnik D, Blaas D. Guiding the location of nanoparticles into vesicular structures: a morphological study. Phys Chem. 2007;9(48):6435-41.

[112] Liu JZ, Hopfiner AJ. Identification of possible sources of nanotoxicity from carbon nanotubes inserted into membrane bilayers using membrane interaction quantitative structureactivity relationship analysis. Chem Res Toxicol. 2008;21(2):459-66.

[113] Hong S, Leroueil PR, Janus EK, Peters JL, Kober MM, Islam MT, et al. Interaction of polycationic polymers with supported lipid bilayers and cells: nanoscale hole formation and enhanced membrane permeability. Bioconjug Cheml. 2006;17(3):728-34.

[114] Teague KO, Fuller NL, Rand RP, Gawrisch K. Polyunsaturated lipids in membrane fusion events. Molecular Biology Letters. 2002;7(2):262-4.

[115] Evans KO, Lentz BR. Kinetics of lipid rearrangements during poly (ethylene glycol) mediated fusion of highly curved unilamellar vesicles. Biochemistry. 2002;41(4):1241-9. 
[116] Breisblatt W, Ohki S. Fusion in phospholipid spherical membranes. II. Effect of cholesterol, divalent ions and pH. Journal of Membrane Biology. 1976;29(1-2):127-46.

[117] Oku N, Shibamoto F, Ito H, Gondo H, Nango M. Low pH induced membrane fusion of lipid vesicles containing proton-sensitive polymer. Biochemistry. 1987;26(25):8145-50.

[118] Swift JL, Carnini A, Dahms TES, Cramb DT. Anesthetic-enhanced membrane fusion examined using two-photon fluorescence correlation spectroscopy. Journal of Physical Chemistry B. 2004;108(30):11133-8. 